Vol. 6, n $1 \mid 2002$

Varia

\title{
Conference «The language of violence» (Koper (Slovenia), 11-13 October 2001)
}

\section{Nella Lonza}

\section{(2) OpenEdition \\ 1 Journals}

\section{Electronic version}

URL: https://journals.openedition.org/chs/279

DOI: $10.4000 /$ chs. 279

ISSN: 1663-4837

\section{Publisher}

Librairie Droz

\section{Printed version}

Date of publication: 1 July 2002

Number of pages: 149-152

ISBN: 2-600-00803-9

ISSN: 1422-0857

\section{Electronic reference}

Nella Lonza, "Conference «The language of violence» (Koper (Slovenia), 11-13 October 2001)", Crime, Histoire \& Sociétés / Crime, History \& Societies [Online], Vol. 6, n¹ | 2002, Online since 03 February 2009, connection on 22 March 2022. URL: http://journals.openedition.org/chs/279 ; DOI: https://doi.org/ $10.4000 /$ chs. 279

This text was automatically generated on 22 March 2022.

(c) Droz 


\title{
Conference «The language of violence» (Koper (Slovenia), 11-13 October 2001)
}

\author{
Nella Lonza
}

1 In October 2001, in a series of biannual international meetings, the Science and Research Centre of the Republic of Slovenia in Koper (www.zrs-kp.si), in collaboration with a number of Slovene, Italian and Croatian scientific institutions, organised a conference on violence in the Mediterranean area from the Middle Ages to the recent past. Some fifty historians, legal historians, historians of art and literature, and historical anthropologists attended. Most of the participants were from Slovenia, Italy, and Croatia, joined by a few colleagues from the U.S. and France. The meeting, which ended with a round table, was presided by Claudio Povolo, Edward Muir, and Darko Darovec, director of the Centre.

2 The conference was held in plenary sessions, with very short presentations, followed by discussion; all the papers will be published in full in the forthcoming proceedings. The conference featured a somewhat random presentation concept, since the papers dealing with allied subjects, approaches or periods failed to cohere around a single theme. However, I do not consider this pattern to be a serious drawback: diversity was one of the principal qualities of the conference. True, meetings with clearly defined and more concentrated contents provide better ground for synthesis or discussion on controversial issues. Nonetheless, the value of this meeting was twofold. First, it helped stimulate research on criminal justice by providing an opportunity for contacts between researchers working in this field and historians who make an occasional appearance or show potential commitment to the topic of violence. Second, the extreme diversity of approach spurred the re-thinking of certain categories, put the methodology to the test, as well as gave rise to fresh ideas. For example, M. Sedmak's research on the contemporary material evidently appealed to many of the historians present. In addition, some aspects of violence and its presentation proved to share unexpected elements, despite their separation in time and space. I also found it very 
pleasant to be given the time to hear and participate in everything, without having to rush from one session to another and miss interesting lectures because they were scheduled at the same hour. The growing number of participants in the Koper meetings over the years may have persuaded the organisers to reconsider the concept of the 2003 conference. My proposal would be to slightly reduce the programme, while preserving a broad scope and diversity, which have proved to be very inspiring. Furthermore, specialists working on other Mediterranean areas would be most welcome.

3 The papers varied in methodology and approach. Some authors introduced completely new or scarcely known sources, which have proved to be very promising for the study of violence. Considerable attention was drawn to the way violence was reported in different historical documents, from early modern chronicles to pamphlets and newspapers. Some papers dealt with the question of narrative, truth and reality in stories of apparent violence.

4 Violence was also treated as a medium of communication between the state and its subjects (in penal rituals, e.g.); as a form of community life; as a tolerated means to convey social tensions and disputes (e.g., feuds); as an element of subculture (within the army, the prison, the Jesuit order, etc.); or even as a symbol of social status (e. g. through the right to bear arms). Many authors shared the view that certain societies have an ambiguous attitude to violence or judge it by a double standard. Several papers investigated the efforts to bring specific violent practices within the frame of legal theory, while others examined attempts to restrain undesirable behaviour by passing stricter laws. In addition, new light was shed on the relation between the type of violence and social structure.

5 A number of papers analysed very sensitive issues of ethnic tensions (e. g. between Slovenes and Italians in the $20^{\text {th }} \mathrm{c}$., among 'mixed' couples in a contemporary society), along with the actions of ethnic and political 'cleansing' after World Wars I and II (the so-called foibe, etc.). Attempts to bring to light episodes and processes which, for political reasons, have remained taboo over the years is becoming a popular exercise particularly among Slovene colleagues, and, while controversial, exemplifies a very important historiographic trend.

6 Many papers emphasised the problem of border and periphery, where the manifestation of violence was specific and particularly intense. I find this aspect worthy of further investigation at one of the future conferences, not only because Koper itself is a multicultural and bilingual community located near a border, nor because we face the re-arrangement of Europe and its boundaries, but primarily because of the challenging and stirring nature of the concept, waiting to be questioned and reconsidered.

7 The conference re-opened some methodological questions which have already received full scholarly attention, and the criticism of the sources sometimes proved much too lenient. Despite the foregoing limitations, though, the Koper conference was a success, and should therefore continue to the benefit of all those interested in «crime, history, and societies» in the Mediterranean basin. Most of all, I hope that the conference proceedings and future studies which might have been inspired by the scheduled or less formal discussions may contribute to a closer collaboration between specialists and help expand the European network of historians dealing with crime and criminal justice into new areas. 


\section{Programme}

\section{Representations of Violence}

8 Claudio Povolo: Introduction; Donald Weinstein: Chivalry and crusade: the utopian vision of Domenico Mora; Dušan Kos: A gallant man and an abducted woman: a tyrant and his victim?; Marco Cavina: Ars iniurandi: Classification and symbolic of offence in the legal treatises on duels during the $15^{\text {th }}$ and $16^{\text {th }}$ centuries; Franco Angiolini: Forms of violence in modern times research suppositions; Lovorka Čoralić: Crime or heroism? Candiot war in Dalmatia according to the chronicle by Franjo Divinić, Šibenik; Matjaž Klemenčič: Violence in the Mediterranean in the light of reports by the Slovene ethnic newspapers in the USA during the 20th century; Damijan Guštin: "An eye for an eye, a bone for a bone?» Responses to the wartime violence in mass media in Slovenia during World War II; Egon Pelikan: The language of violence in the Venezia Giulia region in 1918-1931.

\section{Legality of Violence}

9 Stefano Boccato: Death penalty in Venice in the first half of the $16^{\text {th }}$ century: perception and cultural interactions in Marin Sanudo's diaries; Slaven Bertora: Murders and executions in Pula (1 $17^{\text {th }}-19^{\text {th }}$ centuries); Nella Lonza: The staging of justice: punishment and public space in the Republic of Dubrovnik; Furio Bianco: The languages of power: «Legal reports» and literature from Italian scaffolds (16-18 $8^{\text {th }}$ centuries); Annamari Nieddu: Crime, violence and banditry in the Sardinian provinces. From the potentates' justice to the founding of penal office within the Royal Court in the Kingdom of Sardinia during the $16^{\text {th }}$ and $17^{\text {th }}$ centuries; Alexander Buczynski: Violence in the duty of law and order; Eva Holz: Bitter conflicts between inhabitants of the Pazin County in the second half of the $18^{\text {th }}$ century; Andrej Studen: Fabricated executions. Changes in punishment by death during $16^{\text {th }}-20^{\text {th }}$ centuries; Marta Verginella: The language of violence in the Slovene-Italian national conflict; Jure Gombač: Jews-Slavs-Italians in the devastating «Rižarna» Nazi camp near Trieste (1943-1945); Ivica Pletikosić: «Cleansing» of Piran in the summer of 1947.

\section{Illegitimacy of Violence}

Suzanne Pohl: Classifying homicide: the language of violence in Zuercher manslaughter trials of the fifteenth century; Flavio Rurale: Acts of violence within the Jesuit order and against it in the Padova region during the $16^{\text {th }}$ and $17^{\text {th }}$ centuries; Alisa Plant: The assault on Ste.-Ferme, 1615: desecration and divine wrath in a late episode of the wars of religion; Oscar Di Simplicio: Witchcraft and infanticide $\left(16^{\text {th }}-18^{\text {th }}\right.$ centuries); Ann Tlusty: Household, community, and the right to bear arms in the early modern German city; Nenad Vekarić: Murders amongst relatives in the Republic of Dubrovnik (1667.-1806.); Mauro Gaddi: Women's violence: the case of Friulì; Zdravka Jelaska: Types and forms of violence in Split during the two world wars; Živko Nižić: Koper and the language of violence in the literary perception of Fulvio Tomizza. 


\section{Violence and the Law}

11 Giovanni Chiodi: Moderamen inculpate tutelae. The limits of self-defence from the Middle Ages to modern times; Ante Nazor: With statute against violence - pragmatism or conscience: the case of medieval Croatian community of Poljica; Darja Mihelič: Bloody Court in the $14^{\text {th }}$ century Piran; Gian Paolo Massetto: Torture in Lombard doctrine $\left(16^{\text {th }}-18^{\text {th }}\right.$ centuries); Ettore Dezza: Criminal trial, inquisitorial pattern and state law in Europe in the $16^{\text {th }}$ century; Gorazd Stariha: The violence of prison and the violence in it; Roberto Isotton: Repression of criminal attempt in the penal law scheme in Habsburg and Napoleonic Lombardy; Nevenka Troha: Foibas - crime or justifiable punishment (echoes of the arrests, deportations and executions amongst the local population in the Friuli-Venezia Giulia region).

\section{On the Border}

Giorgio Ravegnani: The end of the imperial rule: violence for power in Byzantium; Darko Darovec: The language of violence and mediaeval pilgrimages in Istran testaments; James Boyden: The "violent against themselves» and the demands of honour in early modern Iberia; Mario Da Passano: 'Bardana' - a cruel and archaic penal act in the $19^{\text {th }}$ century Sardinia; Luciano Faggion: Unrest in the Vicenza aristocracy family: the Trissinos in the second half of the $16^{\text {th }}$ century; Edward Muir: Communities in the Pursuit of Violence in Renaissance Italy; Uršula Lipovec Čebron: Witches and magicians: Manifestation of violence in the oral tradition of Slovene Istria; Claudio Povolo: Blood feud amongst the Venetian aristocracy: Aspects and problems of research; Goran Filipi: Borrowing of the so-called "violent» words as a means of vengeance; Daniela Fozzi: Indiscipline, violence and repression in Italian prisons after the uniting of Italy; Livio Antonielli: Violence and the police: the case of soldiers in the $18^{\text {th }}$ century; Milan Dukedom; Mateja Sedmak: 'God created the earth, but the borders are certainly work of the Devil': Ethnically mixed marriages in the period following Slovenia's attainment of independence; Marco Bellabarba: The pre-war time: the violent recruitment by the Emperor's Army in the second half of the $18^{\text {th }}$ century: Some research inceptions; Rok Stergar: Violence in the army - Austrian army and violence against soldiers in the second half of the $19^{\text {th }}$ century; Bernard Nežmah: Is abuse the same phenomenon for the Catholic theological as well as humanistic studies?

\section{AUTHOR}

\section{NELLA LONZA}

(Institute for Historical Sciences of the Croatian Academy of Sciences and Arts, Dubrovnik), Email: nella.lonza@wxs.nl 